Derhalve concludeert de DRC dat de nieuwe club de sportieve opvolger van PAE is en dat zij gehouden is tot betaling aan de speler van de openstaande schuld, vermeerderd met rente.

NB. De sportieve opvolger is volgens de FIFA-reglementen in beginsel gehouden tot betaling van openstaande schulden van de club waar zij de sportieve opvolger van is. Of er sprake is van een sportieve opvolger is volgens vaste CAS- en FIFA-rechtspraak afhankelijk van alle relevante omstandigheden van het geval, waaronder (zoals hier) vergelijkbare namen, bijna identieke logo's, hetzelfde stadion, dezelfde zetel op hetzelfde adres, dezelfde kleuren en dezelfde geschiedenis.

\section{VSZ 2021/8}

\section{DRC 25 februari 2020, M'Baye (Watford FC v. Mamdaou M'Baye v. Cádiz Club Fútbol)}

Ondertekening arbeidsovereenkomst met nieuwe club levert eenzijdige beëindiging arbeidsovereenkomst met oude club op en leidt tot schadeplichtigheid speler, waarbij ook de nieuwe club mede en hoofdelijk aansprakelijk is voor betaling van deze schadevergoeding.

Volgens de informatie in het Transfer Matching System (TMS) was de Senegalese speler, Mamadou M'Baye (M'Baye), op 27 juli 2018 ingeschreven bij de Engelse club, Watford FC (Watford). Op 23 januari 2019 sloten Watford en de Kroatische club NK Inter Zaprešić (Zaprešić) een uitleenovereenkomst op grond waarvan M'Baye met ingang van 23 januari 2019 tot en met 30 juni 2019 werd uitgeleend door Watford aan Zaprešić. Voorts zouden Watford en M'Baye eveneens op 23 januari 2019 een document hebben ondertekend waarmee zij overeenkwamen dat de arbeidsovereenkomst tussen Watford en M'Baye voor de duur van de uitleenperiode tijdelijk zou worden geschorst. Volgens de informatie in TMS werd M'Baye op 13 augustus 2019 ingeschreven bij de Spaanse club Cádiz Club de Fútbol (Cádiz). Nadat Watford hiervan op de hoogte was gesteld, stuurde deze een e-mail aan Cádiz waarin werd gesteld dat M'Baye een geldige arbeidsovereenkomst met Watford had tot 30 juni 2021. In die e-mail haalde Watford voorts aan dat na voltooiing van de uitleenperiode van M'Baye aan Zaprešić 'de registratie van M'Baye teruggaat naar Watford'. Dit leidde niet tot de door Watford gewenste oplossing en daarop stelde Watford bij de DRC een vordering in tegen M'Baye en Cádiz met het verzoek om onder meer schadevergoeding wegens wanprestatie en om Cádiz hoofdelijk aansprakelijk te stellen voor de betaling van de schadevergoeding. Door middel van een tegenvordering vorderde M'Baye achterstallige salarisbetalingen van Watford.
De DRC oordeelt dat (i) M'Baye een rechtsgeldige arbeidsovereenkomst met Watford had; (ii) hij was uitgeleend aan Zaprešić en; (iii) na zijn uitlening M'Baye verplicht was om naar Watford terug te keren. In plaats van terug te keren naar Watford heeft M'Baye op 13 augustus 2019 een arbeidsovereenkomst met Cádiz ondertekend. De DRC oordeelt dat M'Baye daardoor de facto de arbeidsovereenkomst met Watford op 13 augustus 2019 eenzijdig heeft beëindigd. Dit terwijl Watford door middel van haar pogingen om M'Baye opnieuw in te schrijven en door Cádiz te waarschuwen dat M'Baye nog steeds een geldige arbeidsovereenkomst met Watford had, heeft aangetoond dat zij geïnteresseerd was in de voortzetting van de arbeidsverhouding met M'Baye. Voorts beslist de DRC dat M'Baye, door een arbeidsovereenkomst met Cádiz te ondertekenen, de arbeidsovereenkomst met Watford zonder geldige reden heeft beëindigd. Dat betekent dat M'Baye aan Watford schadevergoeding is verschuldigd. Daarnaast stelt de DRC, overeenkomstig de ondubbelzinnige inhoud van art. 17 par. 2 RSTP, vast dat de nieuwe club van M'Baye, te weten Cádiz, mede en hoofdelijk aansprakelijk is voor de betaling van deze schadevergoeding. Op grond van art. 17 par. 3 RSTP wordt M'Baye daarnaast voor vier maanden uitgesloten van deelname aan officiële wedstrijden. De DRC beslist verder dat, overeenkomstig art. 17 par. 4 RSTP, Cádiz gedurende de twee volledige en opeenvolgende inschrijvingsperioden na de kennisgeving van deze beslissing geen nieuwe spelers mag inschrijven, noch nationaal, noch internationaal. Dit omdat Cádiz niet kan weerleggen dat zij de speler heeft bewogen zijn arbeidsovereenkomst met de oude club te beëindigen zonder geldige reden, waarbij ook meeweegt dat Watford Cádiz had geïnformeerd over het feit dat de speler nog bij haar onder contract stond. De tegenvordering van M'Baye wordt afgewezen omdat hij onvoldoende heeft aangetoond dat Watford niet het overeengekomen salaris zou hebben betaald en bijvoorbeeld ook geen sommatiebrieven waarin hij dit salaris vorderde heeft overgelegd.

NB. Indien een speler tijdens de duur van zijn arbeidsovereenkomst een arbeidsovereenkomst tekent bij een andere club kan dit worden gezien als een beëindiging van de arbeidsovereenkomst met de oude club. Als blijkt dat er geen geldige reden is voor deze beëindiging is de speler schadeplichtig jegens de oude club en is de nieuwe club daarnaast ook mede en hoofdelijk aansprakelijk voor de betaling van een schadevergoeding. Een speler kan (zoals in deze zaak aan de orde) op grond van de FIFA-reglementen bovendien tijdelijk worden uitgesloten van deelname aan officiële wedstrijden als hij buiten de transferperiode zonder geldige reden een arbeidsovereenkomst beëindigt, terwijl de nieuwe club sancties kan krijgen als zij de speler heeft bewogen tot contractbeëindiging met de oude club. 